\title{
TEKNIK BACA SKIMMING, PENULISAN KARYA ILMIAH DAN LITERASI DIGITAL
}

\author{
Jackson Yumame ${ }^{1}$, M. Zaenul Muttaqin ${ }^{2}$, Ilham $^{3}$ \\ ${ }^{1,2,3)}$ Program Studi Ilmu Administrasi Publik, Fakultas Ilmu Sosial dan Ilmu Politik, Universitas \\ Cenderawasih \\ e-mail: jackson_yumame@yahoo.co.id
}

\begin{abstract}
Abstrak
Kegiatan ditujukan bagi mahasiswa yang tidak luput dari tantangan minat membaca dan menulis karya ilmiah yang belum optimal. Berdasarkan fenomena tersebut, dilakukan kegiatan sosialisasi teknik membaca dan workshop penulisan artikel bagi mahasiswa Fakultas Ilmu Sosial dan Ilmu Politik, Universitas Cenderawasih. Pelaksanaan kegiatan ini dilakukan oleh 3 (tiga) orang tim pengabdi dengan pokok bahasan pengantar dan masalah umum dalam kegiatan membaca, teknik membaca cepat dan efektif (Skimming dan Scanning), pilihan bacaan berbasis digital, langkahlangkah menulis karya ilmiah dan, latihan menulis karya ilmiah. Hasil menunjukkan bahwa peserta kegiatan antusias. Terlihat dari banyaknya komentar cara membaca buku baik buku dalam bentuk fisik maupun referensi versi digital serta bentuk tulisan yang layak dipublikasikan.
\end{abstract}

Kata Kunci: Literasi, Teknik Skimming, Karya Ilmiah.

\begin{abstract}
The activity is aimed at students who do not escape the challenges of reading and writing scientific works that are not optimal. Based on this phenomenon, there is a socialization of reading techniques and article writing workshops for students of the Faculty Of Social Sciences and Political Sciences, Cenderawasih University. The implementation of this activity was carried out by 3 (three) service men with introductory subjects and common problems in reading activities, fast and effective reading techniques (Skimming and Scanning), digital-based reading options, scientific writing measures and, scientific writing exercises. Results showed that participants were enthusiastic. It is seen from the many comments on how to read books both in physical form and digital version references as well as forms of writing that are worth publishing.
\end{abstract}

Keywords: Literacy, Skimming Techniques, Scientific Works.

\section{PENDAHULUAN}

Salah satu karakteristik kampus sebagai institusi akademik adalah adanya aktifitas menggali, mengasah ilmu pengetahuan serta bagaimana aplkasi keilmuan itu diterapakan sehingga kegiatan ini menjadi mandatory yang melibatkan dosen maupun mahasiswa. Berlangsungnya proses tersebut tidak lepas dari adanya kegiatan perkuliahan, diskusi, meneliti maupun membaca buku dan penulisan karya ilmiah. Dengan membaca, civitas akademika dapat menjadikannya sumber inspirasi maupun sumber pengetahuan yang akhirnya melahirkan kekritisan yang tinggi. Sehingga kunci wawasan yang luas dan kebebasan berpendapat bertumpu pada sumber bacaan. Kenyataannya sekarang ini muncul permasalahan di perguruan tinggi sebagai ujung tombak pendidikan. Permasalahan tersebut adalah masih ditemukannya minat membaca dan menulis karya ilmiah mahasiswa yang rendah.

Dengan adanya semangat literasi, mahasiswa dapat memperoleh pengetahuan dan mengaplikasikan pengetahuan tersebut melalui kegiatan menulis. Fokus utama kegiatan literasi yang dituju dalam penelitian ini adalah literasi daring atau pemanfaatan sumber-sumber bahan bacaan baik itu buku, jurnal, prosiding, dan sumber bacaan lainnya yang tersedia melalui daring, (Sutrisna, 2018). Permasalahan serupa juga terjadi di lingkungan Universitas Cenderawasih. Sebagai satu kampus besar dan tertua Papua, Universitas Cenderawasih telah dikenal oleh semua lapisan masyarakat, tidak luput dari tantangan yang dijelaskan diatas terkait dengan masih adanya mahasiswa yang kurang dalam minat membaca dan menulis artikel ilmiah. 
Kendala yang ditemui selama mengajar di kelas adalah belum efektifnya aktivitas belajarmengajar. Persoalan tersebut tampak dari kurang aktifnya mahasiswa dalam diskusi kelas dan kualitas dari hasil tulisan ilmiah yang dikerjakan masih jauh dari harapan. Apabila ditinjau lebih jauh, pendapat atau ide dapat diasah melalui banyaknya bacaan. Kualitas pertanyaan yang diajukan mahasiswa dapat dilihat dari jumlah bacaan yang mereka serap sehingga hal ini akan mempengaruhi kualitas dari karya ilmiah yang dihasilkan kedalam bentuk tulisan.

Berdasarkan pengalaman tersebut penulis berencana untuk mengadakan pengabdian masyarakat yang difokuskan dan diperuntukkan ke mahasiswa sebagai bagian dari civitas akademika. Kegiatan yang ingin dilaksanakan adalah "Sosialisasi Teknik Membaca Dan Workshop Penulisan Artikel Bagi Mahasiswa Fakultas Ilmu Sosial Dan Ilmu Politik, Universitas Cenderawasih". Berdasarkan pada uraian analisis situasi di atas, maka permasalahan utama yang dipilih untuk diselesaikan selama pelaksanaan pelaksanaan kegiatan ini adalah memberikan wawasan tentang pentingnya membaca yang dapat meningkatkan daya nalar dan kekritisan mahasiswa dalam diskusi kelas dan catatan tugas perkuliahan dan/serta melakukan pelatihan penulisan artikel/karya limiah sebagai bentuk aktualisasi keilmuan melalui publikasi bagi mahasiswa.

\section{METODE}

Dalam rangka untuk mencari solusi dalam menyelesaikan permasalahan yang dihadapi, maka adapun kegiatan yang kami tawarkan adalah dengan cara melakukan sosialisasi pentingnya membaca, dengan akses perpustakaan maupun sumber tertulis lainnya dan bagaimana pencarian informasi atau referensi penujang dalam penulisan artikel ilmiah. Oleh karena itu, pemberian materi, terbagi menjadi 2 yakni materi sosialisasi dan materi pelatihan sebagai berikut :

1. Sosialisasi pentingnya membaca bagi mahasiswa Fisip Uncen. Hal ini ditujukan untuk meningkatkan daya nalar mahasiswa dalam forum diskusi maupun kualitas karya tulis ilmiahnya.

2. Pelatihan membaca dan menulis bagi mahasiswa FisipcUncen. Kegiatan ini bertujuan untuk mengetahui sejauh mana pemahaman mereka terhadap bacaan.

3. Desain materi kegiatan yang dilaksanakan ini dapat meningkatkan beberapa kemampuan Mahasiswa, diantaranya kemampuan sebagai berikut ini :

4. Memberikan wawasan dan pemahaman mengenai manfaat membaca untuk mangasah kemampuan analisa berpikir.

5. Memberikan pemahaman untuk dapat mengaplikasikan sumber bacaan dalam bentuk tulisan berupa artikel/karya ilmiah.

\section{HASIL DAN PEMBAHASAN}

Target kegiatan pengabdian masyarakat ini meliputi 2 hal yakni target hasil pelaksanaan kegiatan dan dampak dari pelaksanaan kegiatan. Pertama, target dari pelaksanaan kegiatan ini adalah peserta yang mengikuti kegiatan ini mendapatkan sertifikat pelatihan sebagai bukti pernah melaksanakan kegiatan ini dan mampu mengaplikasikan pelatihan yang telah diterima. Kedua, target yang merupakan dampak (long term effect) dari pelaksanaan kegiatan ini yang dipaparkan sebagai berikut ini :

a. Mahasiswa Fisip Uncen dapat memahami manfaat dan pentingnya membaca buku.

b. Mahasiswa Fisip Uncen dapat memahami dan mengaplikasikan teknik/strategi dalam membaca buku.

c. Mahasiswa Fisip Uncen mendapatkan pemahaman, wawasan dan mampu mengaplikasikan sumber bacaannya ke dalam bentuk artikel atau karya ilmiah.

\section{Pelaksanaan Kegiatan}

Pelaksanaan kegiatan terbagi dalam dua tahap, yaitu tahap pertama tentang sosialisasi manfaat pentingnya membaca bagi mahasiswa. Kemudian yang kedua adalah pelatihan menuangkan bacaan ke dalam bentuk penulisan artikel/karya ilmiah bagi mahasiswa di Fakultas Ilmu Sosial dan Ilmu 
Politik telah berjalan sebagaimana direncanakan. Kontribusi peserta dalam pelatihan menjadi parameter suksesi acara sosialisasi dan pelatihan.

Kegiatan dilaksanakan dengan media audio visual Zoom, mengingat adanya pembatasan fisik atau interaksi dengan jarak tertentu. Acara sosialisasi dilakukan dengan metode ceramah dan memberikan introduksi konseptual mengenai materi yakni teknik membaca cepat dan efektif, kemudian dilanjutkan dengan materi pengenalan karya ilmiah termasuk fungsi dan jenis karya ilmiah. Kegiatan ini dilaksanakan selama dua hari dengan pembagian hari pertama sosialisasi dan hari kedua tahapan praktek penulisan. Kegiatan sosialisasi teknik membaca cepat dan pengenalan karya ilmiah berlangsung pada hari Jumat tanggal 4 September 2020 dari Pukul 16.30-20.25 WIT. Peserta kegiatan sebanyak 13 orang berasal dari jurusan yang berbeda di Fakultas Ilmu Sosial dan Ilmu Politik.

Pelaksanaan kegiatan ini dilakukan oleh tiga (tiga) orang tim pengabdi dengan pokok bahasan:

1. Pengantar dan Masalah umum dalam kegiatan membaca.

2. Teknik membaca cepat dan efektif (Skimming dan Scanning).

3. Pilihan bacaan berbasis digital.

4. Langkah-langkah menulis karya ilmiah.

5. Latihan menulis karya ilmiah.

Pada tahap pertama, yakni sosialisasi pentingnya membaca bagi mahasiswa, kegiatan ini meliputi pendampingan kepada mahasiswa untuk menumbuhkan minat baca dengan memaparkan secara lugas manfaat sumber bacaan dalam menunjang kualitas tulisan. Peserta dilatih untuk memilih bacaan yang sesuai dengan bidang yang diminatinya, baik buku umum maupun buku yang berhubungan langsung dengan tugas mata kuliah dan strategi/teknik membaca yang baik dan benar. Dengan keterbukaan informasi publik, literasi informasi, perkembangan pendidikan, serta penyebaran informasi dengan cepat dan tepat bagi masyarakat. Salah satu sumber informasi yang ada dalam perguruan tinggi adalah perpustakaan yang menyimpan koleksi karya tulis yang pada perkembangan sekarang bergeser menyimpan koleksi format non cetak atau koleksi digital, (Furauki \& Sukmana, 2018).

Tahap kedua adalah pelatihan mengelola sumber bacaan ke dalam bentuk tulisan. Dipaparkan bagaimana kerangka tulisan secara rinci, gagasan pokok dan bagaimana idealnya isi artikel memuat gagasan pokok dan sumber bacaan. Pada tahap ini mahasiswa terlatih untuk terbiasa menulis dengan baik dan benar sehingga memenuhi kriteria dari sebuah tulisan ilmiah. Keterbatasan waktu dan media visual mengakibatkan tidak semua materi dapat disampaikan secara rinci sebagaimana acara yang dilaksanakan dengan tatap muka. Keterbatasan ini dialami beberapa peserta dalam bergabung ke dalam acara. Pelaksanaan kegiatan sosialisasi dan pelatihan ini akan dijelaskan secara rinci pada uraian berikut:

\section{Teknik Membaca}

Keterampilan berbahasa mempunyai empat aspek, yaitu keterampilan menyimak (listening skills), keterampilan berbicara (speaking skills), keterampilan membaca (reading skills), dan keterampilan menulis (writing skills). Keempat keterampilan tersebut pada dasarnya merupakan suatu kesatuan yang hanya dapat diperoleh dan dikuasai dengan jalan praktik dan banyak pelatihan. Membaca merupakan salah satu keterampilan berbahasa di samping keterampilan menyimak, berbicara, dan menulis. Keterampilan membaca dapat dipelajari dengan bermacam cara.

Skimming dan scanning, merupakan teknik membaca yang khusus diperlukan dalam membaca cepat dan efektif. Skimming dilakukan dengan proses merekam kata acak secara cepat pada satu teks. Sementara scanning bertujuan untuk menemukan gagasan pokok dalam satu paragraf. Sehingga teknik membaca skimming/scanning merupakan kegiatan membaca yang lebih menyeluruh dan memerlukan kompetensi khusus. Manfaat dari penggunaan teknik skimming/scanning ini yaitu agar lebih mudah untuk memahami isi teks dari suatu bacaan dan dapat menghemat waktu karna dalam menggunakan teknik skimming/scanning ini hanya perlu mencari topik yang mereka cari di dalam daftar isi kemudian melihat sub bab lalu membacanya dengan cepat dengan menggunakan teknik skimming/scanning setelah menentukan apa yang dicari dapat menormalkan kembali bacaan agar dapat memahami isi topik tersebut. Fungsi skimming dan scanning untuk melatih pengelolaan waktu secara mandiri dan efisien. 
Literasi Digital, Perkembangan jumlah data berformat digital di abad sekarang ini begitu menakjubkan. Setiap orang kini memiliki data yang luar biasa lebih banyak dibandingkan masyarakat kita sebelum beralih ke dunia digital, (Priyanto, 2013). Literasi digital mengonfirmasi kebutuhan informasi yang selaras dengan masalah yang dihadapi. Dengan informasi yang efektif pada ranah digital, seseorang menyadari bahkan mengevaluasi informasi yang berlintasan, (Sumarto, 2017). Setiap menit dalam internet, pengguna Youtube mengupload 72 jam konten video baru, pengguna Facebook membagikan 2.460 .000 potongan konten, pengguna Twitter membagikan 277.000 tweet, pengguna Instagram mengupload 216.000 foto dan pengguna Pinterest membagikan 3.472 gambar, (James, 2014).

Jumlah informasi yang tercipta di internet, baik dalam jenis numerik, teks, gambar, audio atau video adalah salah satu ciri bahwa di era ini setiap individu memiliki kebebasan untuk membuat sekaligus menyebarkan tanpa harus ada yang memeriksa ulang apakah informasi tersebut layak memenuhi kriteria atau tidak. Akibatnya, dari tahun ke tahun jumlah informasi yang ada di internet itu akan terus mengalami peningkatan tanpa terkontrol hingga menyebabkan kelebihan informasi (information overload). Informasi yang berlebihan di sisi lain justru menjadi ancaman, bom informasi yang akan berdampak pada dehumanisasi, (Harahap, 2017). Pada akhirnya kelebihan informasi tersebut akan menyebabkan kesulitan bagi setiap individu dalam mencari informasi yang benar-benar bernilai.

Melihat kondisi diatas, maka diperlukan kemampuan literasi digital bagi setiap individu agar dapat dengan mudah dalam mencari, menemukan, mengevaluasi, membuat, memanfaatkan hingga menyebarkan kembali informasi tersebut. Literasi digital memiliki manfaat yang penting bagi setiap individu bahkan dalam beberapa kasus literasi digital dapat mempengaruhi kinerja organisasi. Mahasiswa yang mendapatkan tugas, maka ia akan mengetahui sumber-sumber informasi terpercaya yang dapat dijadikan referensi untuk keperluan tugasnya. Waktu akan lebih berharga karena dalam usaha pencarian dan menemukan informasi itu menjadi lebih mudah.

Pada kasus ini misalnya seorang mahasiswa harus mencari definisi atau istilah kata-kata penting misalnya di glosarium. Dibandingkan dengan mencari referensi yang berbentuk cetak, maka akan lebih cepat dengan memanfaatkan sebuah aplikasi khusus glosarium yang berisi istilahistilah penting. Sumber informasi yang tersedia dan bernilai di internet jumlahnya sangat banyak. Ini bisa menjadi referensi ketika mengetahui dengan tepat sesuai kebutuhannya. Sebagai contoh ketika seseorang akan pergi ke luar negeri, maka akan merasa aman apabila membaca berbagai macam informasi khusus tentang negara yang akan dikunjungi

Mampu menggunakan beberapa aplikasi yang dikhususkan untuk proses komunikasi, maka akan membuat orang akan selalu terhubung. Dalam hal-hal yang bersifat penting dan mendesak, maka ini akan memberikan manfaat tersendiri. Literasi digital membuat indvidu dapat membuat keputusan yang lebih baik karena ia memungkinkan mampu untuk mencari informasi, mempelajari, menganalisis dan membandingkannya kapan saja. Jika Individu mampu membuat keputusan hingga bertindak, maka sebenarnya ia telah memperoleh informasi yang bernilai. Secara umum, informasi dipandang bernilai jika informasi tersebut mempengaruhi penerima untuk membuat keputusan untuk bertindak, (Priyanto, 2013).

\section{Teknik Menulis Artikel Ilmiah}

Artikel ilmiah didefinisikan sebagai analisis fakta berdasarkan pendapat penulis atas fakta. Basis fakta menjadi penting untuk diurai dengan pandangan penulis yang dipadukan dengan teori tertentu, atau dapat dilakukan dengan perbandingan dengan fakta lain dengan penelusuran informasi dan melakukan seleksi terhadapnya. Adapula yang mengartikan artikel ilmiah sebagai opini penulis terhadap peristiwa yang jadi perhatian masyarakat.

Pada umumnya artikel berisi gagasan yang bertujuan memberi tahu, memengaruhi, meyakinkan, bahkan menghibur.

\section{a. Jenis artikel}

Artikel memiliki tiga jenis, yakni: Pertama, artikel praktis yang memuat topik ringan dan disajikan dengan gaya bahasa yang ringan pula. Artikel praktis bersifat tutorial, artinya tidak menyentuh aspek yang mendalam. Kedua, artikel analitis; memakai pendekatan akademis dengan analisis serius, tajam dan mendalam. Pada umumnya artikel analitis banyak dijumpai pada koridor akademis perguruan tinggi dan berbasis riset mendalam. Tujuan artikel analitis adalah menggiring 
pembaca mengikuti jalan pikiran penulis. Terakhir, artikel umum; dengan ciri khas yang serupa artikel analitis. Akan tetapi, artikel umum dapat ditulis siapapun dengan minat pada topik tertentu.

b. Langkah-langkah menulis artikel ilmiah

Persiapan penulisan dengan membangun gagasan dan mengumpulkan informasi sebanyakbanyaknya tentang satu tema. Tahap selanjutnya menuliskannya dengan susunan pendahuluan, isi, dan penutup. Kemudian melanjutkannya dengan melakukan editing. Terakhir adalah penentuan judul.

\section{SIMPULAN}

Kegiatan sosialisasi dan pelatihan penulisan karya ilmiah ini secara keseluruhan telah sesuai target kegiatan dengan susunan rencana kegiatan yang meliputi 2 hal, yakni target hasil pelaksanaan kegiatan dan dampak dari pelaksanaan kegiatan. Jangka panjang sebagai dampak (long term effect) dari pelaksanaan kegiatan ini para peserta dapat memahami manfaat dan pentingnya membaca buku dan mengaplikasikan teknik/strategi dalam membaca buku, serta mendapatkan pemahaman, wawasan dan mampu mengaplikasikan sumber bacaannya ke dalam bentuk artikel atau karya ilmiah.

\section{SARAN}

Perlu ada kegiatan berkelanjutan sehingga literasi digital dapat diakses secara luas dengan penyediaan fasilitas atau prasarana di lingkungan Universitas dengan bekerja sama dengan pihak luar.

\section{UCAPAN TERIMA KASIH}

Penulis mengucapkan terima kasih kepada instansi yang telah memberi dukungan financial terhadap pengabdian ini.

\section{DAFTAR PUSTAKA}

Akhaidah, Sabarti, Arsjad, Maidar G. , dan Ridwan, Sakura H. (1989). Pembinaan Kemampuan Menulis Bahasa Indonesia. Jakarta: Penerbit Erlangga.

Aqua Dwipayana (2003) Kiat Menulis di Media. Jakarta: Global Mahardika

Azahari, Azril. (1998). Bentuk dan Gaya Penulisan Karya Tulis Ilmiah. Jakarta: Penerbit Universltas Trisakti.

Furauki, N. A. F., \& Sukmana, E. (2018). Implementasi Digital Asset Management Upt Perpustakaan ITB. Edulib. https://doi.org/10.17509/edulib.v8i2.12053.

Sutrisna, D. (2018). Meningkatkan Kemampuan Literasi Mahasiswa Menggunakan Google Classroom. FON : Jurnal Pendidikan Bahasa Dan Sastra Indonesia. https://doi.org/10.25134/fjpbsi.v13i2.1544

Tim Penulis. (2018). Pedoman Program Kreativitas Mahasiswa (PKM) Tahun 2018. Direktorat Kemahasiswaan Direktorat Jenderal Pembelajaran Dan Kemahasiswaan Kementerian Riset, Teknologi, Dan Pendidikan Tinggi.

Totok Djuroto dan Bambang Supriyadi (2007) Menulis Artikel dan Karya Ilmiah. Bandung: Rosda Winarto, Yunita., Ibnu Wahyudi., Ezra M. Choesian. (2016). Karya Ilmiah Sosial : Menyiapkan, Menulis, dan Mencermatinya. Jakarta: Pustaka Pelajar. 